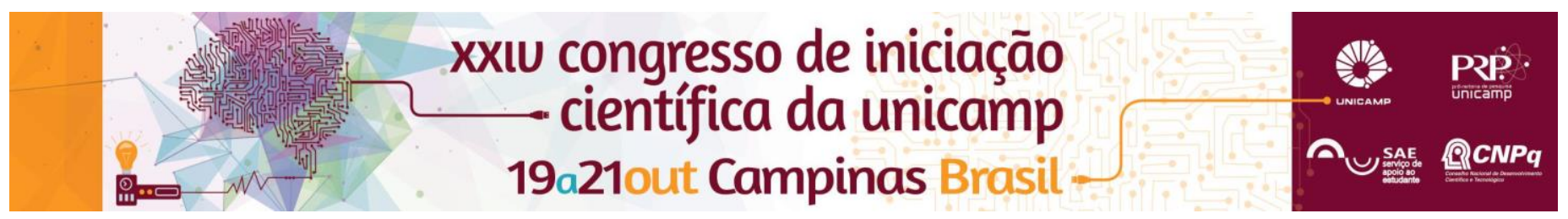

\title{
Evolução recente do desempenho financeiro dos principais times de futebol no Brasil (2009-2015)
}

\section{Marcelo Lopes*, Marcelo Weishaupt Proni.}

\section{Resumo}

A pesquisa teve como objetivo analisar o desempenho financeiro recente dos clubes brasileiros com faturamento anual superior a $\mathrm{R} \$ 100$ milhões. Foram examinados indicadores referentes às fontes de receitas, à composição dos gastos, ao resultado do exercício e à dívida total. Apesar do crescimento das receitas, os clubes continuaram deficitários e altamente endividados, mas há diferenças importantes entre os clubes da elite nacional.

Palavras-chave: Futebol, balanços patrimoniais, desempenho financeiro.

\section{Introdução}

Apesar da crise financeira de 2009, seguiu a tendência de crescimento das receitas no futebol brasileiro. Mas, os gastos se tornaram ainda maiores, sendo equivocada a ideia de que se trata de uma atividade lucrativa.

A pesquisa observou os balanços patrimoniais a fim de perceber diferenças e semelhanças no desempenho financeiro de cada clube, em especial na composição das receitas e dos gastos e no grau de endividamento.

\section{Resultados e Discussão}

Foram selecionados 13 clubes do futebol brasileiro com maior faturamento anual. Foi considerado o período 2009-2015. Os indicadores usados para a análise de balanços patrimoniais são aqueles adotados em estudos similares ${ }^{1}$.

O Gráfico 1 mostra que o total das receitas cresceu até 2013, mas caiu em 2014, em termos reais. Houve quebra das expectativas de que a Copa do Mundo no Brasil traria resultados positivos para os clubes. Em 2015, as receitas se recuperaram, enquanto as despesas ficaram estáveis.

Gráfico 1. Evolução das Receitas, Despesas e Dívidas acumuladas do conjunto dos 13 clubes de maior faturamento. Brasil: 2009-2015. (em milhões de $\mathrm{R} \$$ de dezembro de 2015).

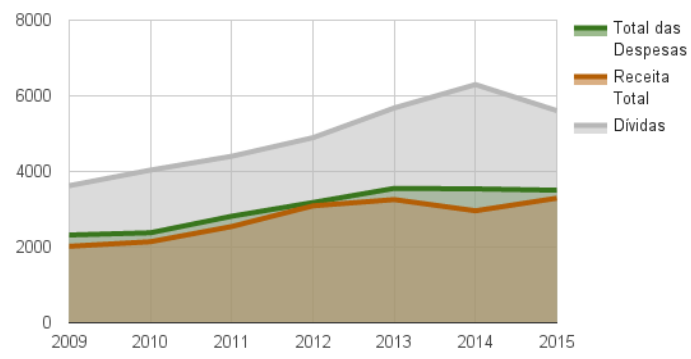

A receita financeira desses clubes se baseia em diversas fontes: direito de transmissão, negociação de atletas, patrocínio, venda de produtos, exploração da marca. A principal fonte de renda é a televisão.

Os gastos também aumentaram junto com o aumento das receitas, mostrando que os clubes não se preocupam com a obtenção de lucros. A maioria das equipes, a cada ano, apresenta prejuízos em seus resultados e, portanto, os clubes se tornam cada vez mais endividados, seja com bancos, seja com a União.
Tabela 1. Receitas, Despesas e Dívidas dos 13 clubes de maior faturamento. Brasil: 2015. (em milhões de R\$)

\begin{tabular}{|c|c|c|c|c|}
\hline & Clubes & Receitas & Despesas & Endividamento \\
\hline 1 & Cruzeiro & 364 & 390 & 290 \\
\hline 2 & Flamengo & 356 & 270 & 579 \\
\hline 3 & Palmeiras & 351 & 341 & 410 \\
\hline 4 & São Paulo & 331 & 403 & 359 \\
\hline 5 & Corinthians & 298 & 396 & 463 \\
\hline 6 & Internacional & 297 & 270 & 281 \\
\hline 7 & Atlético Mineiro & 245 & 257 & 497 \\
\hline 8 & Grêmio & 233 & 270 & 423 \\
\hline 9 & Vasco & 190 & 177 & 468 \\
\hline 10 & Fluminense & 180 & 207 & 462 \\
\hline 11 & Santos & 170 & 287 & 410 \\
\hline 12 & Atlético Paranaense & 158 & 112 & 248 \\
\hline 13 & Botafogo & 121 & 126 & 731 \\
\hline
\end{tabular}

O desempenho financeiro em 2015 foi muito desigual. Por exemplo, o Flamengo teve superávit de $R \$ 114$ milhões, enquanto o Corinthians teve déficit de $R \$ 98$ milhões. O Cruzeiro teve o maior faturamento em razão da venda de atletas e mesmo assim apresentou déficit, enquanto o Botafogo disputou a série B do Campeonato Brasileiro e é o mais endividado da elite nacional.

Em 2015, o Governo Federal, por meio da MP 671 (PROFUT), passou a auxiliar os clubes a financiar suas dívidas com a União, de modo a aliviar a situação financeira dos clubes brasileiros. Com isso, o total das dívidas das equipes da elite se reduziu.

\section{Conclusões}

Os clubes selecionados apresentaram um aumento de seu faturamento ao longo do período, mas seus gastos se tornaram ainda maiores. Em 2014, o aumento das dívidas mostrou a gravidade da situação.

A competição dentro deste seleto grupo está cada vez mais acirrada, o que induz os clubes a realizarem mais investimentos para obterem alto desempenho esportivo. Apesar das estratégias adotadas para aumentar receitas, a venda de jogadores continuou sendo importante para reduzir déficits operacionais.

A gestão dos clubes, em geral, encontra muita dificuldade para sustentar resultados financeiros positivos.

\section{Agradecimentos}

Ao Instituto de Economia da Unicamp e ao PIBIC, que possibilitaram a execução desta pesquisa.

\footnotetext{
${ }^{1}$ ITAÚ-BBA. Análise econômico-financeira dos clubes de futebol brasileiros de 2015: dados financeiros de 2014. São Paulo, 2015; SOMOGGI, A. Finanças dos clubes brasileiros em 2014. Brasília, Congresso Nacional, maio de 2015
} 